\title{
Bioconcentration modelling of alcohol ethoxylates by quantitative structure activity relationship approach: a first look
}

\author{
S.P. Ratnayake* \\ Sri Lanka Institute of Nanotechnology, Nanotechnology and Science Park, Mahenwatte, Pitipana, Homagama.
}

\begin{abstract}
Alcohol ethoxylates (AEs) are a class of nonionic surfactants. This study overviewed the environmental health effects and quantitative structure activity relationships generated for bioconcentration factors of seventeen alcohol ethoxylates, which are currently in commercial use as household detergents. The X-data matrix consisted of 560 molecular descriptors which was calculated by the DRAGON ${ }^{\circledR}$ molecular modelling environment. The logarithms of bioconcentration factors calculated by $\mathrm{EPI}^{\circledR}$ toxicology estimation suite were used as the response factor. Out of two quantitative structure activity relationships generated, one exhibited a model fit of 0.95 and a power of prediction of 0.42 . The second was superior in terms of model fit, which was 0.92 and a power of prediction of 0.7 . The predicted bioconcentration values exhibited a minimum percentage error of $10 \%$ and a maximum of $37 \%$. Prediction accuracy became better with increasing bioconcentration factor. A convincing relationship between bioconcentration and calculated molecular descriptors for alcohol ethoxylates was obtained, hence the capability of quantitative structure activity relationship approach for modelling the environmental behaviour of AEs at a fully empirical level was demonstrated. Constructing a quantitative structure activity relationship having a realistic predictive power over a variety of commercial AEs may be challenging, but with the use of finely tuned chemical descriptors and better modelling tools it could be possible to accurately and rapidly predict toxicities as well as the environmental behaviour of AEs.
\end{abstract}

Keywords: Bioconcentration, molecular descriptors, quantitative structure activity relationship.

\section{INTRODUCTION}

Alcohol ethoxylates (AEs) are a subtype of nonionic surfactants. Most AEs contain a hydrophobic alkyl chain attached to a hydrophilic ethylene oxide (EO) chain by an ether linkage (Figure 1). The AE class also includes alcohol propoxylates and butoxylates. The general formula for an $\mathrm{AE}$ can be expressed as $\mathrm{CH}_{3}-\left(\mathrm{CH}_{2}\right) \mathrm{x}-\mathrm{O}-$ $\left(\mathrm{CH}_{2} \mathrm{CH}_{2} \mathrm{O}\right) \mathrm{y}-\mathrm{H}$ (Boeije et al., 2006).

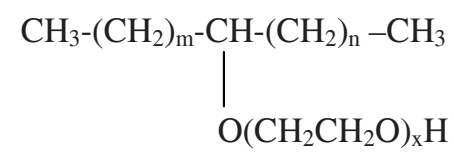

Figure 1: Structure of Softanol ${ }^{\circledR}$ : a commercial secondary AE (ENEOS, 2011)

AEs are commonly used to a larger extent in laundry detergents and all-purpose cleaners, and to a lesser extent in agriculture, cosmetics, and paper production (Talmage, 1994; HERA, 2009). In 2002 over 0.5 million tons of fatty alcohols and fatty-alcohol-based surfactants were estimated to have been consumed in North America, of which approximately $67 \%$ consisted of AEs or sulfated forms of AEs (Modler et al., 2002). The solubility of AEs in water is due to the presence of a strong hydrophilic group (Aveyard, 1984; Swisher, 1987). A mixture of AEs could contain more than 100 different components, which are called ethoxymers. This is due to the presence of many possible combinations of lengths of alkyl chains and the variation of the degree of ethoxylation (Salager, 2002).

Upon entry to the environment, AEs go through processes such as abiotic degradation, adsorption to particles and microbial degradation. Volatilisation is highly unlikely due to the extremely low vapour 
pressures (Balson et al., 2002). The usual disposal pattern for most AEs is through a drainage system. Therefore, their biodegradation occurs mostly within the sewage processing system (Nielson et al., 2002). Studies have shown that a high percentage of AEs released to water are adsorbed to soil particles, and through the process of a sewage treatment plant, undergo anaerobic decomposition. The remaining portion in the aqueous solution undergoes aerobic decomposition (HERA, 2002). Aerobic microbial biodegradation happens to be the most significant process concerning the fate of AEs. Alcohol ethoxylates with multiple branches have shown a slower degradation rate than linear AEs (Birch, 1984; Cardellini \& Ometto, 2001). Alcohol ethoxylates can produce intermediate degradation products, which may include free fatty alcohols, polyethylene glycols and carboxylic fatty acids. Literature suggests that AEs are absorbed rapidly through the gills of fish and are rapidly metabolised and eliminated (Bishop \& Maki, 1980; Newsom et al., 1995; Kiewiet et al., 1997).

The tendency of a substance to bioconcentrate in aquatic organisms is usually expressed as its bioconcentration factor (BCF) (Cummins et al., 1996; Pavan et al., 2008). BCF is defined as the ratio of the concentration of a chemical in an aquatic organism to the concentration of the chemical in surface water, sediment, or soil (USEPA, 1999). It is a unitless quantity. It has been observed that, with the increasing length of the hydrophobic chain, the potential of bioconcentration increases for AEs (Balson et al., 2002). Further, increasing the length of the hydrophilic group decreases the hydrophobicity and results in a reduction of the BCF. When hydrophobicity was increased, higher uptake rates and BCFs for AEs have been observed (Balson et al., 2002). It has been concluded that AEs are not stored in the fish, yet are subjected to rapid biotransformation within their bodies (Tolls et al., 2000). The resultant metabolites of biotransformation were less toxic than the parent compounds. Most BCF values reported for AEs are less than 300 , which is a safe number (Tolls et al., 2000). Octanol water partition coefficient ( $\log$ $\mathrm{K}_{\text {ow }}$ ) values of most of the AEs have been estimated to range between 3 and 7, implying the bioaccumulation of some AEs (Muller et al., 1999).

The toxicity of an individual $\mathrm{AE}$ homologue is a function of its chemical structure and the toxicity has been shown to increase with increasing alkyl chain length and decreasing ethoxylate chain length (Macek \& Krzeminski, 1975; Bishop \& Perry, 1981; Yamane et al., 1984; Dorn et al., 1997; Lizotte et al., 1999; Raney, 2000). Linear AEs have been found to be more toxic than branched AEs (Dorn et al., 1997; Ghirardini et al., 2001). In primary and secondary alcohols, the location of attachment between the alcohol and ethoxylate chains have also been indicated to affect AE toxicity (Kurata et al., 1977). The hardness and temperature of water as well as the homologue distributions in the ethoxylate chain have also been identified to moderate AE toxicity (Lewis \& Hamm, 1986; Garcia et al., 1996). The effects of AEs on reproduction of fish have been demonstrated by previous studies. However, the effects have been shown to be reversible. Change in the reproduction patterns was identified as the most sensitive indicator of AE surfactant effects on fish (Tovell et al., 1975; Dorn et al., 1997).

Current scientific data on the toxic effects of surfactants such as AEs are based mostly on laboratory experiments on a very few species of animals. Therefore, deriving information from existing laboratory data for environmental modelling is challenging. This study attempted to derive a model for BCF of AEs with the quantitative structure activity relationship (QSAR) approach.

\section{METHODOLOGY}

Twenty one AE structures were converted to simplified molecular input line entry system (SMILE) formulas. The derivation was achieved by EPIWEB 4.1 developed by the United States Environmental Protection Agency (USEPA-EPI, 2012). SMILEs data were used for the calculation of 560 molecular descriptors using the Dragon 1.0 molecular modelling environment, developed by the Virtual Computational Chemistry Laboratory of Milano Chemometrics and QSAR Research Group (VCC, 2011). SMILEs are provided in Table I of the Appendix. A brief description and the values of some selected descriptor types are provided in Table II of the Appendix (Todeschini \& Consonni, 2000). BCFBAF, a sub-programme of EPI software suite was utilised to estimate the BCF and its logarithmic value of each compound for fish. This estimation method is currently used in the USEPA developed physico-chemical property and environmental fate estimation programme. Principle component analysis (PCA) and orthogonal partial least squares (OPLS) were used for the QSAR generation using the statistical software package SIMCA P+12.0. Four AEs were used as the prediction group against the generated QSAR models. 


\section{RESULTS AND DISCUSSION}

The complete descriptor dataset was analysed with PCA (Mol. ID: $1-21$ in Table I of Appendix). Five compounds (13, 14, 15, 18 and 19 in Table I of Appendix) were identified as vastly different from the rest of the group according to the hotelling rules of SIMCA, hence were excluded from further analysis. The refined overall set exhibited a segregation based on $\log \mathrm{BCF}$ values (Y-response) according to PCA scores (Figure 2A). Multiple relationships seemed to exist between the molecular descriptors and respective log BCF values. The scores on two principle components (PC) exhibited two distinctive groups (denoted as G-1 and G-2 in Figure 2A and Table 1).

In order to better perceive the relationships between chemical descriptors and log BCF values, G-1 and G-2 were separately analysed by OPLS, hence two QSARs were obtained. G-1 exhibited a weak correlation with model fit $(R 2)=0.95$ and power of prediction $(Q 2)=0.42$. The scores on two PCs are shown in Figure 2B. Further, G-2 exhibited a decent correlation, also on two PCs in the OPLS analysis, with R2 $=0.92$ and Q2 $=0.7$. Unlike G-1, OPLS score positioning also exhibited a pattern of increasing $\log \mathrm{BCF}$ from left to right, hence indicating a more systematic correlation than in G-1 (Figure 2C). The observed vs predicted log BCF values followed a linear pattern, which was also a sign of acceptable model fit (Figure 2D). Four unknown compounds with analogous

Table 1: Compound identification of QSAR-1 and QSAR-2

\begin{tabular}{ll}
\hline Group/QSAR & Compound ID \\
\hline G-1/QSAR-1 & $3,4,6,8,910,12,15,16,19$ \\
G-2/QSAR-2 & $1,2,5,7,11,20,21$ \\
\hline
\end{tabular}

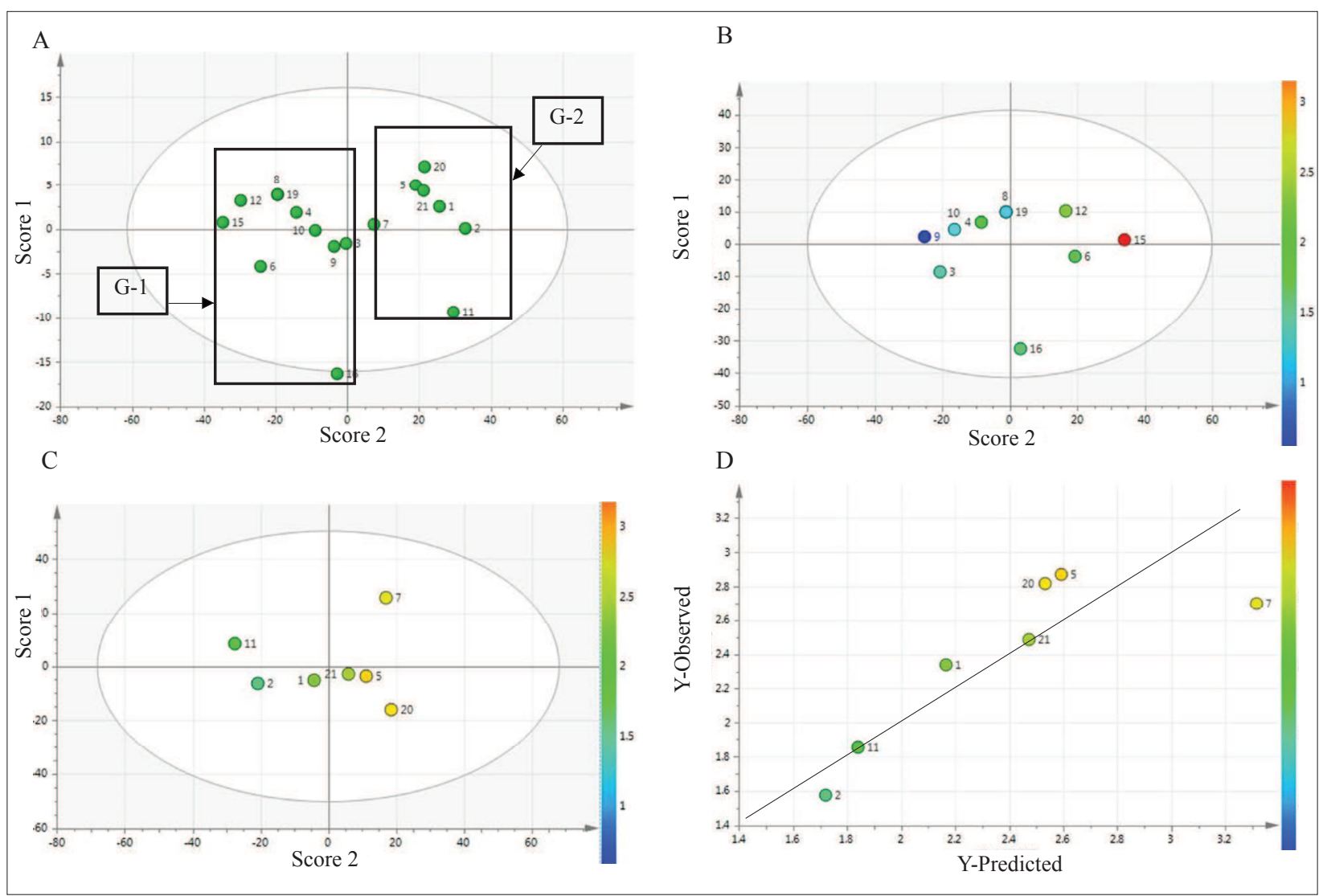

Figure 2: (A) PCA scores exhibiting two groups of AEs (denoted as G-1 and G-2); (B) OPLS scores of G-1; (C) OPLS scores of G-2; (D) observed vs predicted bioconcentration for the G-2 model set of AEs. Compounds colour coded according to BCF. 
physico-chemical characteristics (denoted as compound IDs: 1.1, 1.2, 1.3 and 1.4 in Table 2) were predicted against both generated QSARs (will be denoted as G-1 - QSAR-1 and G-2 - QSAR-2). QSAR-1-predicted $\log \mathrm{BCF}$ values were much lower than those obtained by the $\log \mathrm{K}_{\mathrm{ow}}$ based USEPA-EPI programme. QSAR2-predicted values were observed to be much more accurate. In both QSARs a higher accuracy was observed with increasing $\log \mathrm{BCF}$ value. For compound ID 1.1 the percentage error was $37 \%$ and for compound ID 1.4 it was $10 \%$. The observed $v s$ predicted $\log$ BCFs are given in Figure 3 for QSAR-1 and in Figure 4 for QSAR-2. The exact values predicted from both QSARs are given in Table 2.

Table 2: Predicted log BCF values for designated compounds

\begin{tabular}{|c|c|c|c|c|c|}
\hline ID & SMILE & $\mathrm{CAS} \mathrm{No}^{+}$ & $\begin{array}{c}\text { USEPA } \\
\text { based } \\
\log \mathrm{BCF}^{*}\end{array}$ & $\begin{array}{l}\text { QSAR-1 } \\
\text { predicted } \\
\log \mathrm{BCF}\end{array}$ & $\begin{array}{l}\text { QSAR-2 } \\
\text { predicted } \\
\log \text { BCF }\end{array}$ \\
\hline 1.1 & CCCCCCOCC & 70879-83-3 & 1.655 & 0.267 & 0.698 \\
\hline 1.2 & $\mathrm{CC}(\mathrm{C}) \mathrm{CC}(\mathrm{C}) \mathrm{CC}(\mathrm{C}) \mathrm{CCCOCCOCCOCCOCCOCCO}$ & $68439-54-3$ & 1.771 & 0.635 & 1.342 \\
\hline 1.3 & СССССССССССОСС & $68526-94-3$ & 1.901 & 0.979 & 1.947 \\
\hline 1.4 & ССССССССССССССCCOCC & $69227-20-9$ & 3.074 & 1.282 & 2.995 \\
\hline
\end{tabular}

${ }^{+}$Chemical Abstracts Service registry number

* EPI version 4.1 developed by the USEPA

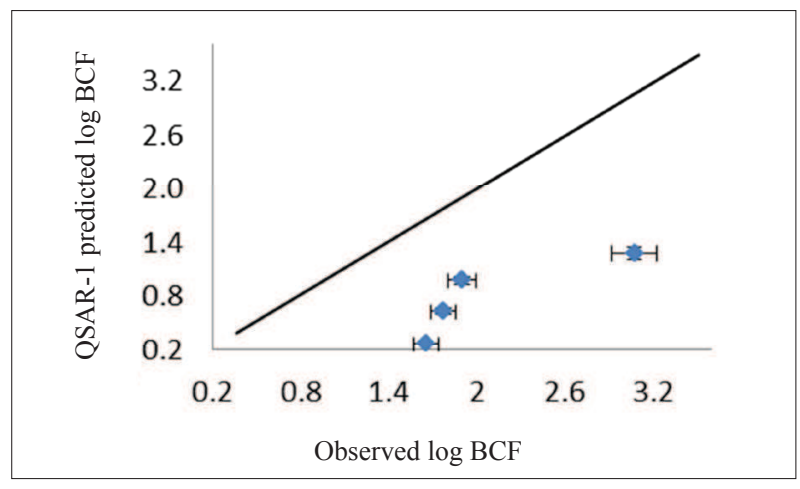

Figure 3: EPI-based $v s$ QSAR-1 predicted log BCF (solid line represents a $100 \%$ match of predicted $\log \mathrm{BCF}$ to observed $\log \mathrm{BCF})$

In comparison to this study, a QSAR constructed by Wong et al. (1997) for acute toxicities of AEs towards two aquatic organisms yielded R2 of 0.98 and 0.99 for Daphnia magna and Pimephales promelas, respectively. Nine AEs were used correlating alkyl and ethoxylate chain lengths to toxicity and the correlations were superior compared to that of the present study (0.92). Willing (2000) demonstrated a relationship for algae where R2 was 0.994. Another QSAR based relationship by Wind and Belanger (2005) produced a QSAR $(n=6)$ with a R2 of 0.586 .

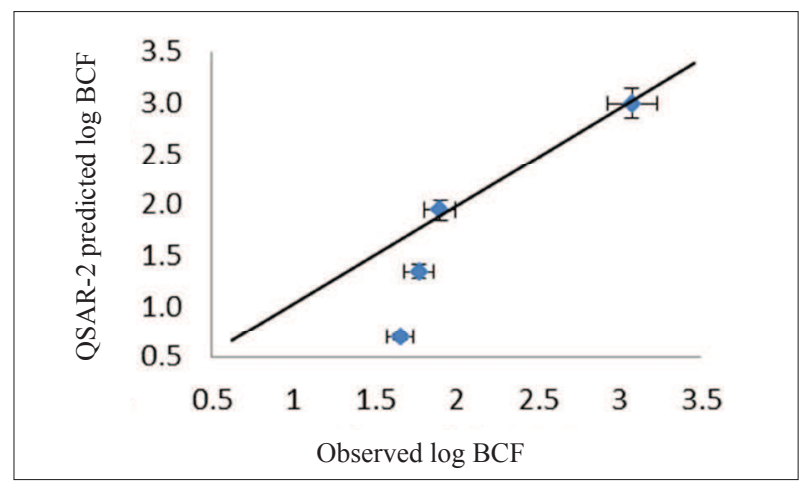

Figure 4: EPI-based vs QSAR-2 predicted $\log \mathrm{BCF}$

\section{CONCLUSION}

AEs seem to have lesser toxicities in both long and short run than other organic chemical compounds of wide use such as pesticides and halogenated flame retardants. The toxicity of AEs seems to increase with increasing alkyl chain length and decreasing ethoxylate chain length.

The QSAR presented by this study signifies the possibility of the QSAR approach for modelling the environmental behaviour of AEs. This study demonstrates 
that structure-derived parameters such as molecular descriptors of AEs could be successfully correlated to activity parameters such as BCF at a fully empirical level. One of the developed QSAR models exhibited a decent model fit and predictive power. However, more AEs would have to be included for the generation of a QSAR relationship that can be used to predict the behaviour of chemically diverse AEs. Since the end result of this type of a model is governed by purely mathematical quantities, for the moment, predictions on environmental fate may have to be made equally based on model predictions and experimental data. Considering the vast number of variables that govern the behaviour of AEs, this type of models have always been complex and challenging to interpret. Besides the inclusion of chemically diverse AEs in the modelling process, additional data such as biodegradation rate and adsorption capability must be studied in detail to generate better elucidations on the complete mechanisms of environmental fate and effects exerted by AEs. With such knowledge it will be possible to select an AE surfactant for each purpose with minimal persistence, bioaconcentration potential and toxicity.

\section{REFERENCES}

1. Aveyard R. (1984). Adsorption at the air/liquid, liquid/ liquid, and solid/liquid interfaces. Surfactants (ed. T.F Tadros), pp. 153 - 173. Academic Press Inc., Toronto, Canada.

2. Balson T., Craddock H.A., Dunlop J., Frampton H., Payne G., Reid P., McWilliams P. \& Payne G. (2002). Bioaccumulation potential of surfactants: a review. Chemistry of Oil Industry VII: Performance in a Challenging Environment, $1^{\text {st }}$ edition, pp. $44-55$. Royal Society of Chemistry, UK.

DOI: http://dx.doi.org/10.1039/9781847550460-00044

3. Birch R.R. (1984). Biodegradation of nonionic surfactants. Journal of American Oil Chemistry 61: 340 - 343. DOI: http://dx.doi.org/10.1007/BF02678791

4. Bishop W.E. \& Maki A.W. (1980). A critical comparison of two bioconcentration test methods. Aquatic Toxicology (eds. J.G. Eaton, P.R. Parrish \& A.C. Hendricks), pp. 61 - 77. American Society for Testing and Materials, West Conshohocken, USA.

DOI: http://dx.doi.org/10.1520/STP27409S

5. Bishop W.E. \& Perry R.L. (1981). Development and evaluation of a flow-through growth inhibition test with duckweed (Lemna minor). ASTM International 737: 421 -435 .

6. Boeije G.M., Cano M.L., Marshall S.J., Belanger S.E., Compernolle V.R., Dorne P.B., Gumbel H., Toy R. \& Wind T. (2006). Ecotoxicity QSARs for alcohol ethoxylates based on the mixture toxicity concept. Ecotoxicity and Environmental Safety 64(1): $75-84$.

DOI: http://dx.doi.org/10.1016/j.ecoenv.2005.08.009
7. Cardellini P. \& Ometto L. (2001). Teratogenic and toxic effects of alcohol ethoxylate and alcohol ethoxy sulfate surfactant on Xenopus laevis embryos and tadpoles. Ecotoxicology and Environmental Safety 48: 170 - 177. DOI: http://dx.doi.org/10.1006/eesa.2000.2005

8. Cummins C.L., Friday G.P. \& Schwartzman A.L. (1996). Radiological Bioconcentration Factors for Aquatic, Terrestrial, and Wetland Ecosystems at the Savannah River Site, Technical Report. Savannah River Technology Center, Aiken, USA. Available at http://pbadupws.nrc.gov/docs/ ML1016/ML101600579.pdf. Accessed 13 June 2013.

9. Dorn P.B., Rodgers J.H., Dubey S.T., Gillespie W.B. \& Lizotte R.E. (1997). An assessment of the ecological effects of a C9-11 linear alcohol ethoxylate surfactant in stream mesocosm experiments. Ecotoxicology 6(5): 275 - 292. DOI: http://dx.doi.org/10.1023/A:1018687029748

10. ENEOS (2011). Chemicals and Structure. Available at http://www.ineosoxide.com/18-Chemicals_and_Structure. htm, Accessed 11 June 2013.

11. Garcia M.T., Ribosa I., Leal S. \& Hreczuch W. (1996). Effect of homologue distribution on the toxicity of alcohol ethoxylates. Journal of American Oil Chemistry Society 73(7): $903-906$.

DOI: http://dx.doi.org/10.1007/BF02517993

12. Ghirardini A.V., Novelli A.A., Likar B., Pojana G., Ghetti P.F. \& Marcomini A. (2001). Sperm cell toxicity test using sea urchin Paracentrotus lividus Lamarck (Echinodermata: Echinoidea): sensitivity and discriminatory ability toward anionic and nonionic surfactants. Environmental Toxicology and Chemistry 20: $644-651$.

DOI: http://dx.doi.org/10.1002/etc.5620200325

13. Human and Environmental Risk Assessment on Ingredients of European Household Cleaning Products (HERA) (2009). Alcohol Ethoxylates. Available at http://www.heraproject. com/files/34-F-09\%20HERA\%20AE\%20Report\%20 Version\%202\%20-\%203\%20Sept\%2009.pdf. Accessed 5 May 2013.

14. Kiewiet A.T., Parsons J.R. \& Govers H.A.J. (1997). Prediction of the fate of alcohol ethoxylates in sewage treatment plants. Chemosphere 34: 1795 - 1801.

15. Kurata N., Koshida K. \& Fujii T. (1977). Biodegradation of surfactants in river water. Yukagaku 26: $115-118$.

16. Lewis M.A. \& Hamm B.G. (1986). Environmental modification of the photosynthetic response of lake plankton to surfactants and significance to a laboratoryfield comparison. Water Resources 20: 1575 - 1582.

17. Lizotte R.E., Wong D.C.L., Dorn P.B. \& Rodgers Jr J.H. (1999). Effects of a homologous series of linear alcohol ethoxylate surfactants on fathead minnow early life stages. Environmental Contamination and Toxicology 37: $536-541$.

DOI: http://dx.doi.org/10.1007/s002449900549

18. Macek K. \& Krzeminski S.F. (1975). Susceptibility of bluegill sunfish (Lepomis macrochirus) to nonionic surfactants. Bulletin of Environmental Contamination and Toxicology 13(3): $377-384$.

DOI: http://dx.doi.org/10.1007/BF01685354 
19. Modler R., Gubler R.F. \& Kishi A. (2002). Surfactants, household detergents and their raw materials. Chemical Economics Handbook. CEH Marketing, Menlo Park, USA.

20. Müller M.T., Zehnder J.B. \& Escher B.I. (1999). Liposomewater and octanol-water partitioning of alcohol ethoxylates. Environmental Toxicology and Chemistry 18: $2191-2198$.

21. Newsom C.S., Howes D., Marshall S.J. \& van Egmond R.A. (1995). Fate of some anionic and alcohol ethoxylate surfactants in Crassius auratus. Tenside Surfactants and Detergents 32: 498 - 503.

22. Nielsen A.M., De Carvalho A.J., McAvoy D.C., Kravetz L. \& Cano M.L. (2002). Investigation of an onsite wastewater treatment system in sandy soil: site characterisation and fate of anionic and nonionic surfactants. Environmental Toxicology and Chemistry 21: $2606-2616$.

DOI: http://dx.doi.org/10.1002/etc.5620211212

23. Pavan M., Worth A.P. \& Netzeva T.I. (2008). Review of literature-based quantitative structure- activity relationship models for bioconcentration. QSAR and Combinatorial Science 27: $21-31$.

DOI: http://dx.doi.org/10.1002/qsar.200710102

24. Raney K.H. (2000). Impact of phase behavior on aquatic toxicity testing of alcohol ethoxylates. Colloidal Surfaces 167: $151-164$.

25. Salager J.L. (2002). Surfactants: Types and Uses. Universidad de Los Andes Mérida, Venezuela. Available at http://nanoparticles.org/pdf/Salager-E300A.pdf. Accessed 7 July 2013.

26. Swisher R.D. (1987). Surfactant Biodegradation, $2^{\text {nd }}$ edition, p. 312. Marcel Dekker Inc., New York, USA.

27. Talmage S.S. (1994). Environmental and Human Safety of Major Surfactants, Alcohol Ethoxylates and Alkylphenol Ethoxylates. The Soap and Detergent Association, Lewis Publishers, Boca Raton, USA.

28. Todeschini R. \& Consonni V. (2000). Handbook of Molecular Descriptors: Methods and Principles in Medicinal Chemistry, volume 14. Wiley-VCH, New York, USA.

DOI: http://dx.doi.org/10.1002/9783527613106

29. Tolls J., Haller M., Labee E., Verweij M. \& Sijm D.T.H.M.
(2000). Experimental determination of bioconcentration of the nonionic surfactant alcohol ethoxylate. Environmental Toxicology and Chemistry 19: $646-653$.

DOI: http://dx.doi.org/10.1002/etc.5620190317

30. Tovell P.W.A., Newsome C. \& Howes D. (1975). Effect of water hardness on the toxicity of a nonionic detergent to fish. Water Resources 9: $31-36$.

31. United States Environmental Protection Agency (USEPA) (1999).ScreeningLevelEcologicalRiskAssessment Protocol for Hazardous Waste Combustion Facilities. Available at https://www.csu.edu/cerc/researchreports/documents/ ScreeningLevelEcologicalRiskAssessmentProtocolHazar dousWasteCombustionFacilitiesVolume3.pdf. Accessed 12 June 2013.

32. United States Environmental Protection Agency EPI Suite $^{\mathrm{TM}}$ (USEPA-EPI) (2012). Available at http://www. epa.gov/oppt/exposure/pubs/episuitedl.htm. Accessed 10 December 2012.

33. Virtual Computational Chemistry Laboratory (VCC) (2011). Available at http://www.vcclab.org/lab/edragon/. Accessed 14 December 2012.

34. Willing A. (2000). Assessment of the ecological properties of various well known and new non-ionic surfactants. Proceedings of the Fifth World Surfactants Congress, Milano, Italy, 29 May - 2 June, pp. 1532 - 1540.

35. Wind T. \& Belanger S.E. (2005). Acute and chronic toxicity of alcohol ethoxylates to the green alga, Desmodesmus (Scenedesmus) subspicatus, and the subsequent development of structure activity relationships. Bulletin of Environmental Contamination and Toxicology 76: $218-225$. DOI: http://dx.doi.org/10.1007/s00128-006-0910-5

36. Wong D.C.L., Dorn P.B. \& Chai E.Y. (1997). Acute toxicity and structure-activity relationships of nine alcohol ethoxylate surfactants to fathead minnow and Daphnia magna. Environmental Toxicology and Chemistry 16: 1971 - 1976.

37. Yamane A.N., Okada M. \& Sudo R. (1984). The growth inhibition of planktonic algae due to surfactants used in washing agents. Water Resources 18: $1101-1105$. 


\section{APPENDIX}

Table I: Chemical and toxicological data of AEs, used for model construction

\begin{tabular}{|c|c|c|c|}
\hline Mol. ID & $\mathrm{BCF}$ & SMILE * & CAS No \\
\hline 1 & 2.337 & $\mathrm{CCCCCCCCC}=\mathrm{CCCCCCCCCOCCOCCOCCOCCOCCO}$ & $61791-28-4$ \\
\hline 2 & 1.577 & СCCCCCCCCCOCC & $66455-15-0$ \\
\hline 3 & 1.442 & СССССССССCOCCOCCOCCOCCO & $68002-97-1$ \\
\hline 4 & 1.909 & 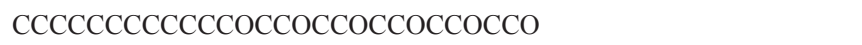 & $68131-39-5$ \\
\hline 5 & 2.873 & ССССССССССССCCOCC & $68154-96-1$ \\
\hline 6 & 1.734 & $\mathrm{CCCCCCCCCCCCCCOCCOCCOCCOCC}(\mathrm{C}) \mathrm{OC}(\mathrm{C}) \mathrm{CO}$ & $68154-98-3$ \\
\hline 7 & 2.699 & $\mathrm{CCOCCCCCCCCC}=\mathrm{CCCCCCCCC}$ & $68155-01-1$ \\
\hline 8 & 1.183 & ССССССССССССССОССОССОССОССОССО & $68213-23-0$ \\
\hline 9 & 0.613 & СССССCССOCCOCCOCCOCCOCCO & $68439-45-2$ \\
\hline 10 & 1.261 & ССССССССССОССОССОССОССОССО & $68439-46-3$ \\
\hline 11 & 1.853 & $\mathrm{CCC}(\mathrm{CCCCCCCC}) \mathrm{OCC}$ & 68551-14-4 \\
\hline 12 & 2.337 & $\mathrm{CCC}=\mathrm{CCCCCCCCCCCCCCCOCCOCCOCCOCCOCCO}$ & $68920-66-1$ \\
\hline 13 & 2.313 & CCCCCCCCOCC & $69013-19-0$ \\
\hline 14 & 2.303 & CCCCCCCCCOC & $71243-46-4$ \\
\hline 15 & 3.439 & 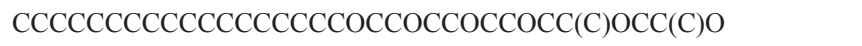 & 73049-34-0 \\
\hline 16 & 1.620 & $\mathrm{C}(\mathrm{C}) \mathrm{CC}(\mathrm{C}) \mathrm{CC}(\mathrm{C}) \mathrm{C}(\mathrm{C}) \mathrm{COCCOCCOCCOCCO}$ & $106232-83-1$ \\
\hline 17 & 2.328 & $\mathrm{C}(\mathrm{C}) \mathrm{CC}(\mathrm{C}) \mathrm{CC}(\mathrm{C}) \mathrm{CC}(\mathrm{C}) \mathrm{CCOCC}(\mathrm{CC}) \mathrm{OCC}(\mathrm{CC}) \mathrm{OCC}(\mathrm{CC}) \mathrm{OCCOCCOCCO}$ & $111905-53-4$ \\
\hline 18 & 1.264 & $\mathrm{C}(\mathrm{C}) \mathrm{CC}(\mathrm{C}) \mathrm{CC}(\mathrm{C}) \mathrm{CC}(\mathrm{C}) \mathrm{CCOCCOCCOCCOCC}(\mathrm{C}) \mathrm{OCC}(\mathrm{C}) \mathrm{O}$ & $111905-54-5$ \\
\hline 19 & 1.183 & $\mathrm{CCCCCCCCCCCCCCOCCOCCOCCOC}(\mathrm{C}) \mathrm{COC}(\mathrm{C}) \mathrm{CO}$ & $139626-71-4$ \\
\hline 20 & 2.900 & ССССССCСCCСCCCCCOCC & $68002-96-0$ \\
\hline 21 & 2.800 & ССССССССССССCCOCC & $68951-67-7$ \\
\hline
\end{tabular}

* SMILE - simplified molecular input line entry system

Table II: A sample of calculated molecular descriptors

\begin{tabular}{cccccc}
\hline Mol. ID & Mv & nSK & Sv & RBF & DELS \\
\hline 1 & 0.503 & 15 & 22.6 & 0.273 & 4.30 \\
2 & 0.502 & 13 & 19.6 & 0.263 & 4.21 \\
3 & 0.518 & 23 & 31.6 & 0.333 & 20.2 \\
4 & 0.519 & 28 & 38.4 & 0.342 & 24.4 \\
5 & 0.503 & 17 & 25.7 & 0.280 & 4.36 \\
6 & 0.518 & 32 & 44.5 & 0.318 & 26.6 \\
7 & 0.512 & 21 & 31.3 & 0.283 & 6.01 \\
8 & 0.518 & 30 & 41.5 & 0.342 & 24.5 \\
9 & 0.521 & 24 & 32.3 & 0.344 & 23.9 \\
10 & 0.520 & 26 & 35.4 & 0.343 & 24.2 \\
11 & 0.502 & 14 & 21.1 & 0.244 & 5.38 \\
12 & 0.523 & 34 & 47.0 & 0.337 & 25.8 \\
13 & 0.500 & 11 & 16.5 & 0.250 & 4.09 \\
14 & 0.502 & 11 & 16.1 & 0.247 & 4.05 \\
15 & 0.517 & 36 & 50.6 & 0.320 & 27.1 \\
16 & 0.517 & 24 & 33.1 & 0.286 & 22.7 \\
17 & 0.518 & 38 & 52.9 & 0.287 & 36.7 \\
\hline
\end{tabular}


- continued from page 449

\begin{tabular}{cccccc}
\hline Mol. ID & Mv & nSK & Sv & RBF & DELS \\
\hline 18 & 0.518 & 31 & 43.0 & 0.280 & 3.16 \\
19 & 0.518 & 30 & 41.5 & 0.342 & 24.5 \\
20 & 0.490 & 17 & 25.2 & 0.270 & 4.27 \\
21 & 0.503 & 16 & 24.9 & 0.277 & 4.34 \\
\hline
\end{tabular}

Mv - Molecular volume

nSK - Number of non $\mathrm{H}$ atoms

$\mathrm{Sv} \quad-\quad$ Sum of atomic van der Waals volumes (scaled on carbon atom)

RBF - Rotatable bond fraction

DELS - Molecular electrotopological variation 